\title{
ÖNKORMÁNYZATI GAZDÁLKODÁS AZ ELSZÁMOLÁSI ÉS BESZÁMOLÓ RENDSZER FOGSÁGÁBAN
}

\author{
(Local Government's Management in the Captivity \\ of Settlement and Reporting System)
}

\section{SIMON JÓZSEF}

Kulcsszavak:

államszámvitel pénzforgalmi szemlélet elhatárolás alapú számvitel

Napjainkban a közpénzügyek területének aktuális kérdése, hogy hogyan valósítható meg az államháztartás korszerüsítése a közpénzek elköltésének szabályossága mellett. Ez utóbbi probléma kezelésére a különbözö országok más és más eszközt alkalmaznak az adott ország berendezkedésétól, tradicionális és kulturális sajátosságaitól függöen. Felismerhetö e folyamatnak egy közös sajátossága, az önkormányzati rendszer hatékonyság javitásának fó eleme a jelenleg érvényes számviteli rendszer megváltoztatása, a pénzforgalmi szemléletü számvitel helyett az „elhatárolás" alapú számvitel alkalmazása. Ez a váltás az országok számára nagy kihivást jelent, a tényleges megvalósítás várhatóan hosszú idōt igényel.

\section{Bevezetés}

Gyakran elhangzik az a vélemény, hogy az államháztartás és ezen belül az önkormányzati rendszer átfogó reformra szorul. E téma egyik kevésbé tárgyalt kérdése az elszámolási és beszámoló rendszer müködésének minósítése és az e területen mutatkozó problémák elemzése. Jelen tanulmány célja rámutatni az elszámolási és beszámoló rendszer jelenlegi múködésének problémáira, valamint ebből kiinduló fejlesztési javaslatok megfogalmazása. A cikk az államháztartás önkormányzati alrendszere szempontjából vizsgálódik, ugyanakkor fontos hangsúlyozni, hogy a következőkben bemutatandó problémák nagy többsége jellemző az államháztartás egészére.

Az elszámolási és beszámoló rendszer sajátosságaiból fakadóan Magyarországon a fó problémát az jelenti, hogy az önkormányzatok sem rendelkeznek elegendö és megfelelỏ mélységü információkkal a gazdálkodásukról. E nélkül azonban nem várható el, hogy egyrészt a közpénzek felhasználása hatékony legyen, másrészt, hogy az önkormányzatok - az elvárásoknak megfelelỏen - bemutassák valós pénzügyi, vagyoni helyzetüket. Véleményủnk szerint az elszámolás - szakmai megfontolásokon nyugvó - törvényi szabályozásával a jelenlegi problémák nagyrészt megszüntethetöek. Ebben kulcsszerepe lehet az „elhatárolás alapú" számviteli rendszer bevezetésének, valamint a pénzforgalmi szemlélet megtartásának azokon a területeken, ahol az eredményszemlélet alkalmazása nem lehetséges, illetve nem jár pótlólagos elönyökkel. 
Simon József : Önkormányzati gazdálkodás az elszámolási és beszámoló rendszer fogságában.

Tér és Társadalom 23. évf. 2009/4. 161-172. p.

\section{A pénzforgalmi szemléletü nyilvántartás jellemzői és következményei}

Az önkormányzati gazdálkodás elszámolási és beszámoló rendszerének törvényi szabályozásában az önkormányzati és az államháztartási törvény mellett a számviteli törvény és a költségvetési szervek sajátos elszámolásait és beszámolási kötelezettségét szabályozó 249/2000 Kormányrendelet játszik jelentős szerepet. Az önkormányzatok által alkalmazott könyvvezetési technika egy sajátos megoldás, amely eltér az üzleti szférában alkalmazott számviteltől. Az önkormányzatok a tevékenységük vagyoni és pénzügyi helyzetére ható eseményekröl a kettös könyvvitel rendszerében, módosított teljesités szemléletü nyilvántartást vezetnek, vagyis a pénzforgalmi szemlélet elvét alkalmazzák. Ez alapján a gazdasági események közül azok kerülnek be a nyilvántartásba, amelyek tényleges pénzmozgással járnak és az adott tranzakció ténylegesen teljesült. Ily módon az önkormányzatok számviteli rendszerében a kiadás és költség kategóriák között nem lehet különbséget tenni, illetve a bevételek és a bevételi elöirányzatok sem különböznek egymástól (Szabó-Szamkó 2001).

A pénzforgalmi szemlélet két fö elönye az egyszerüsége és - a világos interpretálhatóságából következően - az alacsony szakember igénye. Ugyanakkor, ha azt a kérdést tesszük fel, hogy mennyiben felel meg a jelenlegi elszámolási technika a korszerü gazdálkodás igényeinek, akkor egyértelmúen megállapítható, hogy a pénzforgalmi szemlélet nem tesz eleget a hatékony gazdálkodással szemben támasztott követelményeknek. Nézzük, hogy mely tényezőkkel támasztható alá e kijelentés!

A pénzforgalmi szemlélet alapelvéböl adódóan a kötelezettségek és a követelések a könyvvezetésben explicit módon nem jelennek meg, lévén, hogy nem jelentenek konkrét pénzmozgást (Kassó 2000). Ebböl következöen az egyik legfontosabb számviteli alapelv, a teljesség elve nem érvényesül. Az önkormányzatok ugyan dönthetnek úgy, hogy külön analitikus nyilvántartást vezetnek a kötelezettségeikről és követeléseikről, de ez két okból sem minősíthetö jó gyakorlatnak. Egyrészt bármilyen plusz nyilvántartás vezetése költségeket jelent, másrészt nem biztosított az ebből származó információk felhasználása, hiszen addig, amíg nem történik tényleges pénzmozgás, a követelések illetve kötelezettségek rendszeren kívüli tényezỏk. Ráadásul az idő elörehaladtával folyamatosan halmozódnak. A valóságban azonban igenis fontos információt hordoznak, ugyanis ezek együttes figyelembevételével lehet csak a tényleges pénzügyi helyzetet meghatározni. Látszólag a kötelezettségek büntetlenül növelhetők, legalábbis rövid távon, egészen addig, amíg ezek pénzügyi vonzata meg nem jelenik.

A könyvvezetésben az értékcsökkenés gazdasági tartalma sem jelenik meg. Az önkormányzatok számára ugyan meghatározott, hogy a különböző típusú vagyontárgyaik esetén milyen leírási kulcs alkalmazható, azonban az amortizáció - mivel konkrét pénzmozgással nem jár - az elszámolási rendszeren kívüli tényezö. Viszont, ha az elszámolásokban nem jelenik meg az amortizáció, az önkormányzatok vagyontárgyainak piaci és könyv szerinti értéke szükségszerüen eltér egymástól. Ennek következtében a vagyongazdálkodás is kilátástalan helyzetbe kerül. Az önkormányzat többek 
Simon József : Önkormányzati gazdálkodás az elszámolási és beszámoló rendszer fogságában. Tér és Társadalom 23. évf. 2009/4. 161-172. p.

TÉT XXIII. évf. 2009 a 4

Gyors ténykép

163

között nem tudja pontosan meghatározni vagyontárgyainak pótlási időpontját, illetve a vagyontárgy értékesítésekor az eladási ár elmarad a piaci értéktől, amely komoly veszteséget jelenthet az önkormányzat számára. A vagyonnal való gazdálkodás korlátozottsága következtében az önkormányzati feladatok ellátásának minősége sem lesz garantálható.

A pénzforgalmi szemléletből fakadóan az önkormányzatok nem képesek meghatározni az általuk ellátott feladatok tényleges költségét, hiszen csak azon gazdasági események kerülnek rögzítésre, amelyek azonnali pénzmozgással járnak. Ez a technika ugyanakkor a költségvetés összeállításakor is problémát okoz, mert az elszámolt tranzakciók közül számos esemény nem az adott költségvetési évet terheli, és fordítva, számos tétel nem szerepel a tárgy évi költségvetésben, holott annak szerves részét kellene képeznie. A teljes költség ismerete nélkül viszont nem lehet dönteni adott feladat ellátásának optimális szervezeti keretéról, vállalkozási vagy más szervezeti formában történjen-e a feladat megvalósítása, azaz a teljes költség ismerete nélkuil nem lehet eredményesen gazdálkodni az önkormányzat által nyújtott szolgáltatások területén. Tulajdonképpen nem tud érvényesülni a tulajdonosi, befektetői szemlélet, mert valójában a mủkỏdés értékelését ezzel a módszerrel nem lehet elvégezni.

A pénzforgalmi szemlélet azért sem felel meg az önkormányzati gazdálkodás elvárásainak, mert lehetőséget nyújt a gazdálkodási problémák elfedésére, a rossz gazdasági helyzetet kedvezỏnek lehet feltüntetni. Az átláthatóság követelménye sem képes érvényesülni. Létezik ugyan belső ellenőrzés, azonban elsősorban a törvényeknek, jogszabályoknak való megfelelés minősítését végzi. De az önkormányzatok elszámolási rendszerével kapcsolatban a jogszabályokat kellene megváltoztatni. Lehet a belső ellenőrzés kitủnő minősítésével szemben a gazdálkodás pazarló, ha a költségvetés, költségvetési évről készített beszámoló pénzforgalmi jellegü adatokra épül, a valós megbízható gazdálkodásról szóló összkép nem teljesülhet, a beszámoló előírt tagolása még a korlátozott információtartalom „kinyerését” is megakadályozza. Ez tág mozgásteret ad a statikus mérlegegyezőség elvtelen létrehozásához. Az utóbbihoz egyébként a finanszírozási nehézségek is hozzájárulnak.

A gazdálkodás objektív megítélését tovább nehezítik a beszámoló rendszer hiátusai. A gazdálkodás alapinformációinak pontatlansága, illetve nem teljes körüsége következtében az önkormányzatok gazdálkodásáról készített beszámolók nem adnak valós képet a gazdálkodás hatékonyságáról. A mérleg szinte minden vagyoni kérdéssel összefüggó döntés megalapozására alkalmatlan. A vagyonmérleg sok-sok félrevezetó adatot tartalmaz. Nemcsak az értékelés elve átláthatatlan és követhetetlen, hanem kifejezetten alkalmas a döntéshozók félrevezetésére. Az adott információk a céloknak megfelelően értékelhetők, kedvező és kedvezőtlen értékekként is magyarázhatók.

A gazdálkodás hatékonyságának mérése szinte lehetetlen. Az üzleti szférában alkalmazott gazdasági mutatók számítása korlátokba ütközik, és a kapott eredmények fenntartásokkal kezelendők. Ezzel a problémával fóként az önkormányzatok gazdasági partnerei szembesülnek, akiknek minősíteniük kell az adott önkormányzat gazdasági helyzetét a kockázatok csökkentése érdekében, de ez nem lehetséges releváns 
információk hiányában. A minősítés szükségessége különösen fontos és aktuális kérdés a hazai pénzügyi szolgáltatók számára, mert az önkormányzatok eladósodása egyre nagyobb mértékủ. A hitelintézetek korábban alkalmazott stratégiája, mely szerint az önkormányzatoknak érdemes hitelt nyújtani, mert nemteljesítés esetén az állam úgyis támogatni fogja a bajba jutott önkormányzatot, napjainkra kezd megváltozni. A hitelintézetek óvatosabbak az önkormányzatok hitelezésében, hiszen számukra is nyilvánvalóvá vált, hogy a hazai önkormányzatok többsége forráshiányos, és a közel 3200 önkormányzat kétharmada nem képes ellátni a kötelezö feladatait sem, vagyis az önkormányzatok túlnyomó részének nincs megfelelö pénzügyi kapacitása a hitelek fedezetéhez.

A politikai döntéshozók szempontjából a pénzforgalmi szemlélet alkalmazása a költségvetés tervezésében látszólag előnyösnek tủnik, hiszen a költségvetésből egyértelmúen látható, hogy a közpénzekből mely intézmények és milyen mértékben részesülnek, és a tárgyév zárását követően a beszámolók visszatükrözik az adott források elköltését. Vagyis a döntéshozók számára úgy tünhet, mintha a kívánt célok teljesültek volna. Az intézménycentrikus finanszírozási technika ily módon háttérbe szorítja a közpénzek hatékony elköltésének kérdését, és egyedül arra ad választ, hogy mely intézmény mekkora összeget költött el az adott év során. Tehát a feladatot ellátó intézmény tényleges teljesítménye nem mérhető, vagyis a feladatok megfelelő színvonalú ellátása nem garantálható. Ez a fajta érvelés nézetünk szerint csak féligazság. Rövid távon, éven belül dominálhatnak a fenti politikai érdekek, hosszú távon, éven túl a közügyek felé elkötelezett politikus számára nemcsak a pénzügyi források útja, hanem költségtakarékos elköltése is legalább olyan fontos. Korlátozottan rendelkezésre álló források esetén azok hatékony felhasználása is kulcskérdés.

Az államháztartáson belül, így az önkormányzatoknál is az érdekeltek információigényének kielégítése a számviteli rendszer múködtetésén keresztül lehetséges. A jelenlegi szabályozás legfóbb problémája, hogy Magyarországon a pénzforgalmi szemléletủ könyvvezetés és az erre épülő beszámoló-készítési gyakorlat nem szolgálja az önkormányzati gazdálkodás érdekeit, az információk többnyire hamisak, s generálják a pazarlás lehetőségét, $\mathrm{s}$ magát a pazarló gazdálkodást.

A számvitel és a kötelező struktúrában elöirt adatszolgáltatás jól, rosszul - döntỏen a költségvetési tervezést és a közpénzekkel való elszámolást, illetve ezen elszámolást kísérő külső és belső ellenőrzés igényeinek kielégítését szolgálja (Kassó 2000). A magyar államháztartás gazdálkodási gyakorlatában a szủkebb számvitel és ezen belül is a könyvvitel öncélúvá vált, gyakorlatilag semmilyen visszajelzỏ szerepkört nem tölt be. Azon túl, hogy a tényleges költségvetési döntési folyamatot és gazdálkodási gyakorlatot nem szolgálja, nem biztosítja a választók és a gazdasági partnerek információs igényeinek kielégítését. Ez különösen a pénzforgalmi szemléletre való 1992-es, az ÁHT életbelépésével bekövetkezett átállás miatt van így. A problémát fokozza, hogy az államháztartási számvitel, így az önkormányzatok számvitele is, beszámoló rendszere által elóállítja a pénzügyi beszámoló kötelezỏ elemeit, de ezek fiktív adatokkal operálnak. A vállalkozási szektor pénzügyi beszámolóival megegyező formák ráadásul egy sor felhasználót megtévesztenek. Gyakorlatban sokszor 
Simon József : Önkormányzati gazdálkodás az elszámolási és beszámoló rendszer fogságában. Tér és Társadalom 23. évf. 2009/4. 161-172. p.

TÉT XXIII. évf. 2009 - 4

Gyors ténykép

165

elöfordul, hogy kívüiállók, jellemzően bankok és más pénzügyi szolgáltatók az önkormányzati „vagyonmérlegekböl” és eredmény kimutatásokból a standard pénzügyi mutatószámokat képezik, és ezek alapján minősítik az önkormányzatokat (Nagy et al. 2004).

\section{Elhatárolás alapú szemlélet jelentösége és jellemzöi}

Az előzőek alapján elfogadhatjuk azt a hipotézist, hogy Magyarországon a pénzforgalmi szemlélet jelen körülmények között nem felel meg az önkormányzati gazdálkodás igényeinek. Ha ez így van, akkor meg kell vizsgálni azt a kérdést, hogy milyen más elszámolási alapelv alkalmazható, és ez milyen jellemzökkel rendelkezik.

A közszféra elszámolási és beszámoló rendszere alapvetően két módszer szerint épülhet fel, az egyik a korábbiakban már jellemzett pénzforgalmi szemlélet, a másik pedig az elhatárolás alapú szemlélet ${ }^{l}$. A pénzforgalmi szemlélettel ellentétben az elhatárolás alapú számviteli rendszerben a gazdasági események nem a pénzforgalom tényleges megtörténtekor kerülnek a nyilvántartásba, hanem az ún. elméleti realizáltság pillanatában. Vagyis minden egyes gazdasági eseménynél meg kell határozni, hogy mikor tekintjük teljesültnek. Például a szociális segély esetén ez az időpont lehet az igénylés elfogadásának időpontja, a kiutalás napja vagy azon időpont, amikor az állampolgár ténylegesen hozzájut az adott összeghez.

A gyakorlatban ugyanakkor nagyon sokszor fordul elö, hogy e két elv alkalmazása párhuzamosan történik, bizonyos területeken a pénzforgalmi, míg más területeken az elhatárolás alapú számvitel kerül alkalmazásra. A következőkben az elhatárolás alapú számvitel jellemzésével foglalkozunk, tesszük ezt azért, mert ennek ismeretében már megfogalmazhatóvá válnak fejlesztési javaslataink a hazai önkormányzati rendszer számára.

\section{Elhatárolás alapú számvitel megjelenése}

Az 1950-es évektôl kezdődỏen szinte minden fejlett európai államban a közszektor mérete folyamatosan növekedett, ami alapvetően az állami feladatok bővülésének volt a következménye. Később, a nyolcvanas évektől kezdődően nyilvánvalóvá vált, hogy a minden helyzetben segítỏ és minden társadalmi probléma megoldását finanszírozó államháztartás koncepciója érvényét vesztette. Az állampolgárok ugyanakkor egyre inkább kritikus szemmel figyelték az államháztartás költekezését, és joggal fogalmazódtak meg a napjainkban is különösen érvényes elvárások a közszféra átláthatóságára, elszámoltathatóságára és hatékonyságára vonatkozóan. E két forrásból táplálkozva születtek meg a közszféra menedzsmentjének különbözö irányzatai, amelyek közül számos irányzat az államháztartás múködési elveiröl, feladatairól, a közigazgatás szükséges átalakításairól elmélkedett, míg a többi irányzat a gyakorlatban alkalmazott technikák hatékonyságának javítá- 
Simon József : Önkormányzati gazdálkodás az elszámolási és beszámoló rendszer fogságában.

Tér és Társadalom 23. évf. 2009/4. 161-172. p.

166 Gyors ténykép

TÉT XXIII. évf. 2009 @ 4

sával foglalkozott. Ez utóbbi elméletek közös ismérve, hogy meggyőződésük szerint a magánszférában alkalmazott módszerek sikerrel alkalmazhatók a közszférában is. A gyakorlati irányultságú elméletek közül jelentösége és kidolgozottsága alapján kiemelkedik a New Public Management irányzat. Több más javaslata mellett az irányzat fỏ hipotézise, hogy a közszférában, hasonlóan az üzleti vállalkozásokhoz, alkalmazandó az elhatárolás alapú szemlélet, mert ily módon a gazdálkodásról teljes körủen rendelkezésre állnak a szükséges információk, amelyet a döntéshozók felhasználhatnak az állampolgárok igényeinek jobb kielégítése érdekében. Az irányzatot követö szerzők ugyanakkor eltéröen látják megvalósíthatónak az elhatárolási szemlélet bevezetését. A szerzők egy csoportja szerint a közszférában nem alkalmazható teljes körủen az elhatárolás alapú szemlélet, a közszféra sajátos jellemzőinek következtében. Az elutasítás során a legtöbbet hivatkozott érv, hogy a közszféra intézményei nem profitorientáltak, szemben a magánszféra szervezeteivel (JonesPuglisi 1997; Olson et al. 1998; Matheson-Kwon 2003). A másik nézőpont szerint a megvalósítására mindenképpen szükség van, és nagy valószínủséggel eredményes lehet a váltás (Shand 1990; Rhodes 1998). A harmadik csoportba pedig azon szerzők tartoznak, akik ugyan támogatják az új szemlélet térhódítását, de szerintük csak bizonyos területeken lehet ez eredményes (Barton 1999; Christiaens-Rommel 2008).

\section{Elhatárolás alapú számvitel elönyei és hátrányai}

Ezen a ponton segítségül hívhatjuk a közgazdaság egyik alapvetö módszerét, a költség-haszon elemzést, hiszen alkalmazásával elméletileg megítélhető, hogy az elhatárolás alapú szemlélet bevezetése „,kifizetödö-e” vagy sem. Ennek érdekében össze kell gyüjtenünk az elhatárolás alapú szemlélet alkalmazásának előnyeit és hátrányait. Egy adott ország esetén alkalmazva a módszert természetesen a bevezetés kérdésének megítéléséhez szükség van a tényleges és számszerüsített hozamok és költségek becslésére.

Az elhatárolás alapú szemlélet elönyei között tulajdonképpen ugyanazon jellemzők szerepelnek, amelyek a pénzforgalmi szemlélet hátrányaiként azonosíthatók. A szemlélet segítségével az önkormányzat képes a gazdálkodás folyamatainak naprakész nyomon követésére, a követelések és a kötelezettségek a nyilvántartásokban explicit módon megjelennek, azaz nem kell ezek nyomon követésére külön nyilvántartási rendszert vezetni. Továbbá a követelések és a kötelezettségek ismeretében a gazdálkodás tényleges eredménye, vagyis jellemzően a hiány, ritkábban a szufficit összege egyértelmüen adódik, és ami a legfontosabb, nincs lehetöség az adatok önkényes befolyásolására.

A gazdasági események teljes körü rögzítéséböl fakadóan adott feladat tényleges költsége meghatározhatóvá válik, és ami legalább ennyire fontos, hogy lehetöséget nyújt az évek közötti összehasonlításra, valamint a feladat ellátásának optimális módjának meghatározására. Az eredmények és a ráfordítások ismeretében az önkormányzati döntéshozók sokkal pontosabban tudnak tervezni, és a költségvetési év 
Simon József : Önkormányzati gazdálkodás az elszámolási és beszámoló rendszer fogságában. Tér és Társadalom 23. évf. 2009/4. 161-172. p.

TÉT XXIII. évf. 2009 - 4

Gyors ténykép

167

során a kitüzött célok teljesülése is mérhetövé válik. Ily módon az elhatárolás alapú számvitel segítségével hatékonyabbá és eredményesebbé válhat az erőforrás felhasználás. A gazdálkodásról rendelkezésre álló információk következtében az önkormányzatoknál lehetôvé válik a pénzügyi vezetés színvonalának javítása és a mérhetöséggel összefüggésben a vezetöi teljesítmények szélesebb körben értékelhetők, és a szükséges visszacsatolások megtehetök. Továbbá az előzőekben ismertetett elönyök az önkormányzati rendszer szintjén biztosítják az elszámoltatás és az elszámoltathatóság feltételeinek érvényesítését is. Az önkormányzat vezetöinek szempontjából az elhatárolás alapú szemlélet elösegíti a gazdálkodás folyamatainak jobb megismerését és megértését, ami által nyilvánvalóvá válik az adott egységnyi közpénz elköltésének hasznosulása (Wynne 2004; Nyikos 2005).

Az előnyök mellett az elhatárolás alapú szemlélet kapcsán számos hátrány is megemlíthető. E tényezők alapvetően két csoportba sorolhatók. Az első csoportba az elhatárolás alapú szemlélet bevezetésének és müködtetésének technikai költségei, míg a másik csoportba a különböző nyilvántartások vezetésének költségei tartoznak. A technikai költségek között szerepelnek a számviteli informatikai rendszer kidolgozásának, müködtetésének költségei, az informatikusok betanításának költségei, a számviteli szakemberek alkalmazásának és továbbképzésének költségei, valamint a számviteli módszerek, eljárások kidolgozásának költségei. Az elhatárolás alapú szemléletet bevezetô országok esetében az elszámolási és beszámoló rendszer mủködtetésére fordított összeg dinamikusan emelkedett.

A hátrányok mellett az elhatárolás alapú szemléletnél fellépnek bizonyos kockázatok is, amelyek a pénzforgalmi szemléletnél, annak viszonylagos egyszerủsége következtében kevésbé vagy egyáltalán nem jelentkeznek.

A fellépỏ kockázatok a szakirodalom alapján (Diamond 2002; IFAC 2003; KhanMayes 2007; Christiaens-Rommel 2008) a következök:

- A komplex információs rendszer alkalmazása következtében gyengülhet a vezetök irányító képessége;

- Kiszorító hatás léphet fel - a bevezetésre költött közpénzek más területektől vonhatnak el szükséges forrásokat;

- A bevezetést követően a rendszer nem teljesít az elvárt szinten és ennek következtében a gazdasági folyamatok ellenőrzése lehetetlenné válik;

- A nemzetközi standardok tartalmának meg nem értése;

- A nemzetközi standardok helytelen adaptációja;

- A nemzetközi standardok korlátozott alkalmazása, a teljes adaptáció megvalósítására való törekvés hiánya;

- A számviteli rendszer átalakításában a politikusok meghatározó szerepe;

- Az elhatárolás alapú szemlélet által nyújtott információk figyelmen kívül hagyása, például az ellenőrzési rendszer módszereiben;

- Az elhatárolás alapú elszámolási rendszer és a pénzforgalmi szemléletủ költségvetés közötti illeszkedési problémák; 
Simon József : Önkormányzati gazdálkodás az elszámolási és beszámoló rendszer fogságában. Tér és Társadalom 23. évf. 2009/4. 161-172. p.

- Az újonnan kialakított informatikai rendszerigényeknek való meg nem felelése;

- A politikai döntéshozók az elhatárolás alapú információkat kevésbé értik meg.

Az elhatárolás alapú szemlélet bevezetése még önmagában nem jelenti az önkormányzati gazdálkodás hatékonyságának javulását. E cél eléréséhez szuikség van a hátrányként jelentkezỏ költségek finanszírozására és a kockázatok kezelésére. Az adaptációban élenjáró országok példája jól mutatja, hogy az elhatárolás alapú szemlélet bevezetésének általános kerete áll csupán rendelkezésre iránymutatások, elméleti ajánlások formájában, azonban az adaptáció menetrendjének, konkrét tartalmának meghatározásakor minden esetben az adott állam közszférájának jellemzöit kell szem elött tartani. Ezen állítás természetesen érvényes a magyar államháztartásra és ezen belül az önkormányzati rendszerre is.

\section{Nemzetközi tendenciák}

Az elhatárolás alapú számvitel megvalósítása a gyakorlatban meglehetősen színes képet mutat. Az egyes országok eltérỏ elveket vallanak arról, hogy az elhatárolás alapú számviteli rendszerre milyen mértékben van szükség. Valamint abban is különbség figyelhetö meg az egyes országok között, hogy milyen mértékben látják megvalósíthatónak adott körülmények között az elhatárolás alapú szemléletet.

Az 1. táblázat alapján az országok két fó csoportba sorolhatók, az egyik csoportba azon országok tartoznak, amelyek pénzforgalmi szemléletet alkalmaznak, és csak néhány területen érvényesítik az elhatárolási szemléletet, míg a másik csoportba azon országok sorolhatók, amelyek az elhatárolási szemléletet szélesebb körben használják. De ezen országok között is különbséget lehet tenni aszerint, hogy az elhatárolás alapú szemléletet az államháztartás mely szintjén alkalmazzák, csak az önkormányzati rendszerben vagy/és a központi szinten is.

Az elhatárolás alapú szemlélet térhódítása folyamatos és lassú folyamat. Mindez számos tényezö következménye. Az áttérésben élen haladó országok esetén a kiküszöbölendő fó probléma, hogy az elhatárolás alapú szemlélet bevezetésének minden buktatóját még nem sikerült legyözni, számos olyan terület maradt, amelyen változtatni kell a siker érdekében. E területek közé sorolható többek között a pénzügyi vezetés fejlesztése, a politikai döntéshozók informáltságának javítása, a rendelkezésre álló keletkezett információk jobb hasznosítása, a nemzetközi számviteli standardok megértése és helyi igényekhez igazítása, a közszférában dolgozók, különösen a számviteli szakemberek képzése, az informatikai eszközök hasznosítása. Ezen országokról szóló jelentések pedig elbizonytalanítják a változtatást még csak tervező országokat, és könnyen a pesszimizmus csapdájába kerülnek. A pénzforgalmi szemléletet alkalmazó országok esetén a váltást vagy az előbbi indok magyarázza, vagy pedig az, hogy az áttéréshez szükséges előfeltételek nem teljesülnek. Ezek közül is kiemelhető a politikai szándék, amely alapfeltételnek tekinthetö. 
Simon József : Önkormányzati gazdálkodás az elszámolási és beszámoló rendszer fogságában. Tér és Társadalom 23. évf. 2009/4. 161-172. p.

TÉT XXIII. évf. 2009 - 4

Gyors ténykép

\section{TÁBLÁZAT}

Elhatárolás alapú számvitel a különbözó országokban

(Accrual Accounting in the Different Countries)

\begin{tabular}{ll}
\hline \multicolumn{1}{c}{ Ország } & \multicolumn{1}{c}{ Bevezetés idópontja és területe } \\
\hline Európai uniós tagállamok & Speciális területeken - bevételek és kiadások \\
Ausztria & nyilvántartása elhatárolás alapú \\
Belgium & Sem alkalmazott \\
Csehország & nyilvántartása elhatán - befektetett eszközök \\
Dánia & 2000 óta \\
Észtország & 2000 óta \\
Finnország & 1990 óta. Központi és helyi szinten \\
Franciaország & 2007 óta. Központi és helyi szinten \\
Hollandia & 1980 óta. Helyi szinten \\
Lettország & 2000 óta \\
Litvánia & Speciális területeken - befektetett eszközök \\
Luxemburg & nyilvántartása elhatárolás alapú \\
Málta & Nem alkalmazott \\
Nagy-Britannia & Bevezetés folyamatban van \\
Németország & 2004 óta. Helyi szinten \\
Olaszország & 2000 óta. Helyi szinten (néhány önkormány- \\
Portugália & zatnál) \\
Románia & 2000 óta. Helyi szinten \\
Spanyolország & Nem alkalmazott \\
Svédország & 2007 óta. Központi és helyi szinten \\
Szlovénia & 1990 óta. Központi és helyi szinten \\
$\quad$ Egyéb országok & 1990 óta. Központi és helyi szinten \\
Ausztrália & Nem alkalmazott \\
Egyesült Államok & \\
Kanada & 1997 óta. Központi szinten \\
Svájc & 1997 óta. Központi és helyi szinten \\
Új-Zéland & 2001 óta \\
\hline
\end{tabular}

Forrás: Saját szerkesztés.

Ugyanakkor az elhatárolás alapú szemlélet terjedésének azonosítható egy szignifikáns hajtóereje is, ez pedig a különböző nemzetközi szervezetek e szemléletet támogató tevékenysége. $\mathrm{E}$ körböl is kiemelkedik az IFAC ${ }^{2}$, amely többek között kidolgozta a nemzetközi számviteli standardokat a közszféra számára, illetve minden évben elemzéseket, összehasonlító tanulmányokat készít az egyes tagországok közszférájának számviteli gyakorlatáról. 


\section{Fejlesztési javaslatok}

Magyarországon a jelenlegi elszámolási rendszer jellemzői nincsenek összhangban a döntéshozók elvárásaival. A döntéshozatalhoz szükséges információk a gazdálkodás számos területén egyáltalán nem vagy csak korlátozottan állnak rendelkezésre, ezzel szinte kilátástalan helyzetbe hozva a gazdálkodás hatékony irányítását.

A jelenlegi helyzetet vizsgálva megállapítható, hogy az önkormányzati rendszer, és ezen belül az elszámolási és beszámoló rendszer modernizációja tovább már nem halasztható. Ebben a kérdésben tökéletes egyetértés van az önkormányzati szakértök között, azonban a tekintetben, hogy a fejlesztés során milyen lépésekre van szükség, már megoszlanak a vélemények. Ugyanakkor fontos hangsúlyozni, hogy nem a gazdálkodás egyes részterületeinek elszigetelt fejlesztése a fő kérdés, hanem komplex fejlesztési program kidolgozása, melynek elemei egymással harmonizálnak. Erre példaként említhető a finanszírozás és az önkormányzati feladatok köre között feszülő ellentét. Mind az önkormányzatok, mind a kormányzat a másik oldaltól várja a megoldást, azonban több szakértő is egyértelmủen rámutatott, hogy $a$ finanszírozási rendszer és a feladatellátás reformja csak akkor lehet sikeres, ha egymással párhuzamosan történik.

A továbbiakban a tanulmány fỏ témájával összhangban az elszámolási és beszámoló rendszerrel kapcsolatos fejlesztési javaslatokat mutatjuk be. Véleményünk szerint ezt a kérdéskört is tágabb kontextusba kell beágyazni, vagyis az információs rendszer átgondolására is szükség van. Elsöként azt kell eldönteni, hogy a gazdálkodás irányításához kinek, milyen információkra van szüksége, ezeket hol és milyen módszerekkel lehet előállítani (Kassó 2006).

Az elszámolási és beszámoló rendszer fejlesztését tekintve az alapvető kérdés, hogy továbbra is a pénzforgalmi szemlélet legyen a nyilvántartási elv, vagy történjen elmozdulás az elhatárolás alapú számvitel irányába. Véleményünk szerint a fejlesztési tervben különböző szakaszokat kell elkülöníteni, abból fakadóan, hogy az önkormányzati rendszer minden egyéb jellemzöjét együttesen figyelembe kell venni.

Az elsó szakasz addig tartana, amíg az önkormányzati rendszer minden fontos koncepcionális problémája megoldódik. Erre jellemzỏ, hogy a pénzforgalmi szemlélet megőrizendő, de a jelszó legyen „Csináljuk hatékonyabban”. Mindez azt jelenti többek között, hogy az információs rendszerben biztosítsuk a meglévő információk megfelelö kezelését, a követeléseket és a kötelezettségeket naprakészen tartsuk nyilván, a finanszírozásban az intézményi szemlélettel szemben érvényesüljön a feladatra való koncentrálás, a zárszámadás legyen logikus felépítésủ. Ez a megoldás ugyan nem biztosít tökéletes átláthatóságot és elszámoltathatóságot, ugyanakkor elérhetó lenne, hogy a jelenleginél nagyságrendekkel hasznosíthatóbb információk keletkezzenek, ami jó alapot biztosít a továbblépéshez.

A második fejlesztési szakaszban merülhet fel az elhatárolás alapú számvitel bevezetése. A nemzetközi tapasztalatok azt mutatják, hogy az elhatárolás alapú számvitel alkalmazása lassan terjed. Az áttérésben élen haladó országok példája 
Simon József : Önkormányzati gazdálkodás az elszámolási és beszámoló rendszer fogságában. Tér és Társadalom 23. évf. 2009/4. 161-172. p.

szerint az új szemlélet bevezetése csak akkor lehet sikeres, ha minden elöfeltétel teljesül, és sikerül leküzdeni a buktatókat. E területek közé sorolható többek között a pénzügyi vezetés fejlesztése, a politikai döntéshozók informáltságának javítása, a rendelkezésre álló keletkezett információk jobb hasznosítása, a nemzetközi számviteli standardok megértése és helyi igényekhez igazítása, a közszférában dolgozók, különösen a számviteli szakemberek képzése, az informatikai eszközök hasznosítása. Hazánkban e területek fejlesztése különösen indokolt, hiszen meglehetősen nagy a lemaradásunk a nyugat európai államokkal szemben, amelyek tradicionálisan elkötelezettek a közszféra modernizációja iránt.

További fontos kérdés, hogy mely területeken érdemes alkalmazni az új szemléletet. Véleményünk szerint első lépésben olyan feladatok nyilvántartásánál és elszámolásánál, amelyek viszonylag közel állnak a magánszférához, pl. vállalkozási tevékenységek. E tekintetben az önkormányzati rendszer különösen alkalmas terepe lehet az elhatárolás alapú számvitel bevezetésének, hiszen az államháztartáson belül az önkormányzati rendszer nyújtja a legtöbb szolgáltatást, és a szolgáltatások többségénél alkalmazható a ráfordítás eredmény szemlélet. Ugyanakkor az átállás kezdeti időszakában ki kell választani néhány ún. mintafeladatot és mintaönkormányzatot, amelyeknél a bevezetés tesztelhetô, és így a későbbiekben a többi önkormányzatnál a feltárt hibák már kiküszöbölhetök lesznek. A következő lépésben kerülhetne kiterjesztésre az elhatárolás alapú szemlélet minden olyan önkormányzati feladatnál, amelyeknél az elhatárolás alapú szemléletböl fakadó előnyök kihasználhatók.

Az elhatárolás alapú szemlélet alkalmazása egyben egy kiinduló alapot is jelent a gazdálkodás hatékonyabbá tételére, azonban ennek a lehetőségnek a megragadása már az adott önkormányzat attitüdjén, hozzáértésen múlik, vagyis hogy ki tudja-e használni a keletkező információtömeget. Ugyanakkor az új szemlélet fejlesztő hatása tovább fokozható bizonyos módszerek alkalmazásával, ide sorolható például a teljesítmény menedzsment alkalmazása vagy az elhatárolás alapú szemlélet alkalmazása a költségvetés tervezésekor.

Az elhatárolás alapú szemlélet bevezetésével párhuzamosan a második fázisban szükség van a finanszírozási rendszer átalakítására is, hiszen az elszámolási és beszámoló rendszer reformja jelentős költségekkel jár. Nagy-Britanniában például az új szemlélet bevezetését követően a számviteli szakemberek munkabérére költött pénzösszeg csaknem háromszorosára növekedett, illetve az informatikai eszközök beszerzésére fordított összeg elérte az éves költségvetés majdnem 10\%-át. Ugyanakkor az önkormányzati feladatoknál a tényleges költség ismerete által a döntéshozók nagyságrendekkel nagyobb költségvetési megtakarításokat érnek el. Hazánkban további kulcskérdés, hogy jelenleg a könyvvezetésben meg nem jelenő amortizáció finanszírozása milyen forrásokból történjen. Hiszen az amortizáció gazdasági tartalmának megjelenése az önkormányzatok számára jelen körülmények között elviselhetetlen terhet jelentene.

A pénzforgalmi szemlélet ugyanakkor továbbra is alkalmazandó azon feladatok esetén, amelyeknél az elhatárolás alapú szemlélet alkalmazása nem lehetséges vagy alkalmazása nem jár pótlólagos előnyökkel. Példaként említhető a szociális segélyezés, 
Simon József : Önkormányzati gazdálkodás az elszámolási és beszámoló rendszer fogságában.

Tér és Társadalom 23. évf. 2009/4. 161-172. p.

amelynél az eredmény nem értelmezhető racionálisan, az önkormányzat szempontjából a kifizetés ténye és jogszerüsége bír kitüntetett jelentőséggel.

$\mathrm{Az}$ önkormányzati rendszer elszámolási és beszámoló rendszerének átalakítása során törekedni kell az elhatárolás alapú szemlélet bevezetésére. Az átállás - meggyőződésünk szerint - azonban csak akkor lehet sikeres, ha az önkormányzati rendszer „konfliktus konténer” szerepe megszűnik, és a szakmai javaslatok alapján a rendszer föbb problémái megoldásra kerülnek.

\section{Jegyzetek}

${ }^{1}$ Az elhatárolás alapú számvitel tulajdonképpen az üzleti szférában alkalmazott eredményszemléletủ számvitel közszférára átalakított megoldása. A hazai szakirodalomban Kassó Zsuzsanna használta elsőként e fogalmat.

${ }^{2}$ IFAC - Könyvvizsgálók Nemzetközi Szövetségének rövidítése.

\section{Irodalom}

Barton, A. (1999) Public and Private Sector Accounting - The Non-Identical Twins. - Australian Accounting Review. 2. 22-31. o.

Christiaens J.-Rommel J. (2008) Accrual accounting reforms: only for businesslike (parts of) governments. - Financial, Accountability \& Management. 1. 59-75. o.

Diamond, J. (2002) Performance Budgeting - Is accrual accounting required? IMF Papers No. 240. IMF, New York.

IFAC (2003) Transition to Accrual Based Accounting? Guidance for Governments and Governments Entities. International Federation of Accountants, New York.

Jones, S.-Puglisi, N. (1997) The Relevance of AAS29 to the Australian Public Sector: A Cause for Doubt? - Abacus. 1. 115-132. o.

Kassó Zs. (2000) Az államszámvitel fogalma, feladata, lehetséges megoldási módjai. IGE Kft., Budapest.

Kassó Zs. (2006) Miért van szuikség az államháztartás pénzïgyi beszámolórendszerének változtatására? -

Vígvári A. (szerk.) Decentralizáció, transzparencia, elszámoltathatóság. IDEA, MKI, Budapest. 83-130. o.

Khan, A.-Mayes, S. (2007) Public Financial Management Technical Guidance Note. MMF, New York.

Matheson, A.-Kwon, H.S. (2003) Public Sector Modernisation: A New Agenda. - OECD Joumal on Budgeting. 1.7-23. o.

Nagy K.-Kajdi J.-Legeza Ö. (2004) Az önkormányzati adósságregiszter kialakításának megalapozása. http://www.onkormanyzati.hu/ar_tanulmany.pdf (Letöltve: 2008.03.10.)

Nyikos L. (2005) Államszámvitel fö kérdései jelenleg Magyarországon.

www.attentus.hw/Local\%20folder/Tanulmanyok/allamszvitel.pdf (Letöltve:2008.04.12.)

Olson, O.-Guthrie, J.-Humphrey, C. (1998) Growing Accustomed to Other Faces: The Global Themes and Warnings of Our Project. Global Warning! - Olson, O.-Guthrie, J.-Humphrey, C. (eds.) Debating International Developments in NewPublic Financial Management. Cappelen Akademisk Forlag, Oslo. 435-466. o.

Rhodes, R. (1998) Different Roads to Unfamiliar Places: UK Experience in Comparative Perspective. Australian Journal of Public Administration. 4. 19-31. o.

Shand, D. (1990) Australia Moves to Accrual Accounting: Problems and Prospects. - Forster, J.-Wanna, J. (eds.) Budgetary Management and Control: the Public Sector in Australasia. Macmillan, Melbourne. 142-150. o.

Szabó M.-Szamkó J. (2001) Költségvetési szervek számvitele. Perfekt Rt., Budapest.

Wynne, A. (2004) Is the move to accrual based accounting a rela priority for public sector accounting? IFAC, London. 